Terbit online pada laman web jurnal : http://e-journal.sastra-unes.com/index.php/JIPS

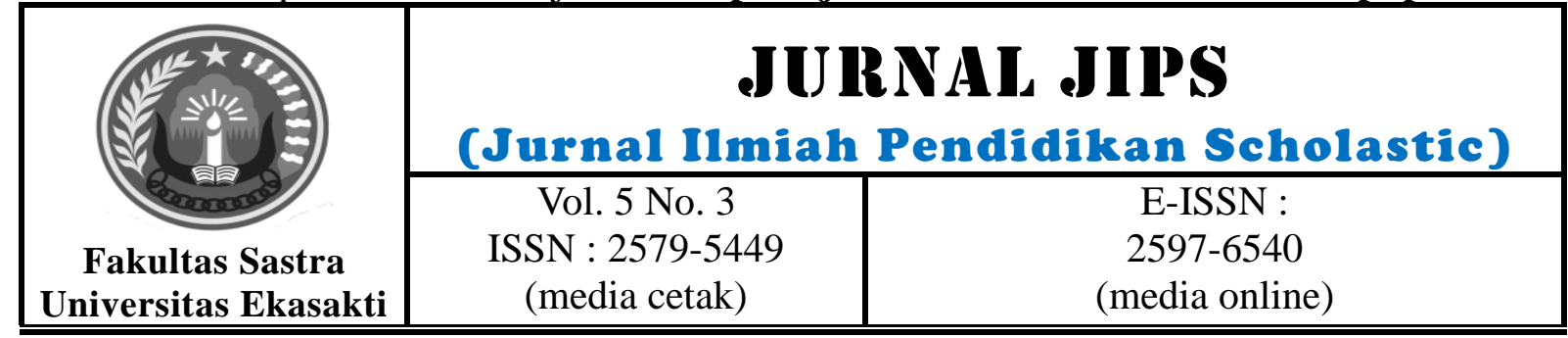

\title{
EFEKTIVITAS LEMBAR KERJA PESERTA DIDIK (LKPD) MENGGUNAKAN MODEL PEMBELAJARAN DISCOVERY LEARNING TERHADAP KEMAMPUAN PEMAHAMAN KONSEP DAN PEMECAHAN MASALAH MATEMATIS
}

\author{
Teni Suriani, Dewi Devita \\ Dosen Program Studi Pendidikan Ekonomi FKIP Universitas Ekasakti, tenisuriani@unespadang.ac.id \\ Dosen Program Studi Pendidikan Teknologi Informasi dan Komputer Universitas Putra Indonesia Yptk Padang, \\ dewidevita@upiyptk.ac.id
}

\begin{abstract}
Kemampuan pemahaman konsep dan pemecahan masalah matematis merupakan tujuan mata pelajaran matematika dan diharapkan dapat dikembangkan dalam pembelajaran matematika. Berdasarkan observasi yang dilakukan pada siswa kelas VII SMP N 38 Padang tahun pelajaran 2019/2020 diperoleh informasi bahwa siswa sering mengalami kesulitan ketika mengerjakan soal cerita atau soal yang berkaitan dalam kehidupan sehari-hari tanpa disertai dengan ilustrasi gambarnya. Hal ini disebabkan pembelajaran matematika masih cenderung berfokus pada buku paket dan LKPD. LKPD yang ada disekolah masih kurang bervariasi dan belum ada langkahlangkah kerja siswa untuk menemukan dan mengkonstruksi sendiri konsep pembelajaran. Salah satu model pembelajaran yang dapat dikembangkan adalah dengan menggunakan model Discovery Learning.

Discovery learning merupakan pembelajaran dimana ide atau gagasan disampaikan melalui proses penemuan. Penelitian ini memiliki tujuan menghasilkan dan mengembangkan lembar kerja peserta didik (LKPD) dengan menggunakan model pembelajaran Discovery Learning yang efektif. Jenis penelitian ini menggunakan model pengembangan development research tipe formative evaluation menurut pandangan Tessmer. Efektivitas diselidiki melalui tes kemampuan pemahaman konsep dan pemecahan masalah matematis siswa yang dianalisis dengan menggunakan rubrik kemampuan pemahaman konsep dan pemecahan masalah. Hasil uji Efektivitas LKPD kemampuan pemahaman konsep dan pemecahan masalah matematis siswa diperoleh persentase ketuntasan belajar siswa kelas eksperimen dengan menggunakan LKPD berbasis discovery learning lebih tinggi dari pada siswa kelas kontrol.
\end{abstract}

Keywords: Model Pembelajaran Discovery Learning; Efektifitas; LKPD

(C) 2021Jurnal JIPS

Jurnal JIPS (Jurnal Ilmiah Pendidikan Scholastic) Vol. 5 No. 3 (2021) ISSN : 2579-5449

This work is licensed under a Creative Commons Attribution-NonCommercial 4.0 International License. 


\section{INTRODUCTION}

Matematika merupakan ilmu universal yang berguna bagi kehidupan manusia dan juga mendasari perkembangan teknologi modern, serta mempunyai peran penting dalam berbagai disiplin dan memajukan daya pikir manusia. Perkembangan pesat dibidang teknologi informasi dan komunikasi dewasa ini dilandasi oleh perkembangan matematika dibidang teori bilangan, aljabar, analisis, teori peluang, dan matematika diskrit. Untuk menguasai dan mencipta teknologi dimasa depan diperlukan penguasaan dan pemahaman atas matematika yang kuat sejak dini.

Berdasarkan observasi yang dilakukan pada siswa kelas VII SMP N 38 Padang tahun pelajaran 2019/2020 diperoleh informasi bahwa siswa sering mengalami kesulitan ketika mengerjakan soal cerita atau soal yang berkaitan dalam kehidupan sehari-hari tanpa disertai dengan ilustrasi gambarnya. Hal ini disebabkan pembelajaran matematika masih cenderung berfokus pada buku paket dan LKPD. Dari hasil pengamatan LKPD yang digunakan tidak memenuhi karakteristik yang sudah ditetapkan dan tidak mengacu pada scientific approach. LKPD hanya menyajikan materi sangat ringkas sehingga siswa tidak melihat proses untuk menemukan konsep tersebut.

Salah satu model yang dapat digunakan untuk permasalahan diatas adalah model pembelajaran Discovery Learning. Discovery learning merupakan pembelajaran dimana ide atau gagasan disampaikan melalui proses penemuan. Proses pembelajaran diawali pemberian rangsangan, identifikasi masalah, pengumpulan data, mengolah dan menafsirkan data, pembuktian serta menarik kesimpulan. Pengembangan LKPD dengan Discovery Learning diharapkan dapat mempermudahkan peserta didik dalam memahami materi pembelajaran terutama pada materi yang cukup sulit untuk dipahami sehingga peserta didik mampu meyelesaikan permasalahan yang berhubungan dengan soal tersebut. Pengembangan LKPD dengan Model pembelajaran Discovery Learning pada materi matematika diharapkan dapat membantu peserta didik memahami materi tersebut dengan baik, sehingga menghasilkan LKPD dengan Model pembelajaran Discovery Learning yang efektif.

LKPD didefinisikan sebagai suatu bahan ajar cetak berupa lembar-lembar kertas yang berisi materi, ringkasan, dan petunjuk-petunjuk pelaksanaan tugas pembelajaran yang harus dikerjakan oleh peserta didik dengan mengacu Kompetensi Dasar (KD) yang harus dicapai (Andi Prastowo, 2012: 204). Halini sesuai dengan definisi LKPD menurut Trianto (2010: 111) Lembar Kerja Peserta Didik (LKPD) merupakan panduan peserta didik yang digunakan untuk pengembangan aspek dalam bentuk panduan kegiatan penyelidikan atau pemecahan masalah sesuai indikator pencapaian hasil belajar yang harus dicapai.

\section{RESEARCH METHOD}

Jenis penelitian yang dikembangkan pada pengembangan perangkat pembelajaran berupa LKPD dengan model pembelajaran Discovery Learning adalah model penelitian development research tipe formative evaluation menurut pandangan Tessmer (Plomp 2007:28). Tujuan dari penelitian ini adalah untuk melihat produk yang efektif. Menurut Tessmer (Plomp 2007:28) Ada 4 tahapan pengembangan yaitu:

1. Self Evaluation

a. Analisis

Tahap ini merupakan tahap dimana dilakukan analisis terhadap karakteristik siswa dengan tujuan untuk menentukan kelas penelitian, dan sebagai acuan dan pertimbangan dalam membuat perangkat pembelajaran berupa LKPD yang cocok sesuai dengan karakteristik siswa kelas penelitian.

\section{b. Desain}

Tahap desain yang dimaksud adalah mendesain perangkat pembelajaran berupa LKPD. Mendesain LKPD didasarkan atas pemikiran dan disesuikan dengan Model pembelajaran Discovery Learning). Penelitian ini menghasilkan prototipe LKPD pertama

Jurnal JIPS (Jurnal Ilmiah Pendidikan Scholastic) Vol. 5 No. 3 (2021) ISSN : 2579-5449

This work is licensed under a Creative Commons Attribution-NonCommercial 4.0 International License. 
(hasil self evaluation) dan prototype kedua (revisi dari expert review).

\section{Expert Review dan One-to-one}

Hasil desain pada prototipe pertama yang dikembangkan atas dasar self evaluation diberikan pada pakar (expert review) dan dua orang siswa (one-to-one) untuk mengamati,mengkomentari, dan memberikan saran.

\section{a. Uji Pakar (expert judgement)}

Pada tahap uji pakar, bahan ajar LKPD yang telah didesain akan dicermati, dinilai dan dievaluasi oleh panelis. Panelis terdiri dari tiga orang dalam bidang ilmu pendidikan. Panelis akan menelaah conten, konstruks dan bahasa dari masing-masing prototipe. Saran- saran panelis/validator digunakan untuk merevisi bahan ajar.

\section{b. One-to-one}

Pada tahap one-to-one, memanfaatkan dua orang sebagai testee dan diminta untuk mengamati, mengkomentari bahan ajar berupa LKPD yang didesain. Hasil komentar dari bahan ajar akan dijadikan dasar untuk merevisi bahan ajar yang didesain. Hasil uji pakar (expert judgement) dan one-to-one menjadi dasar untuk merevisi bahan ajar yang didesain (prototipe pertama). Hasil revisi dari uji pakar (expert judgement) dan one-to-one menghasilkan prototype kedua.

\section{Small Group (kelompok kecil)}

Hasil prototipe kedua diujicobakan pada lima orang siswa non subjek penelitian. Tahap ini siswa diminta untuk menyelesaikan dan mengomentari bahan ajar yang telah direvisi berdasarkan masukan dari expert judgement dan one-to-one (prototipe kedua). Hasil dari uji small group akan dijadikan dasar untuk merevisi bahan ajar prototipe kedua. Hasil revisi tersebut dinamakan prototipe ketiga (produk).

\section{4. $\quad$ Field Test ( Uji lapangan )}

Pada pelaksanaan field test, prototipe ketiga (produk) diujikan ke subjek penelitian yaitu siswa kelas VII.G SMP N 38 Padang. Pelaksanaan field test melihat kepraktisan dan efektivitasnya. Kepraktisan yang dimaksud dalam penelitian ini yaitu produk mudah digunakan (dimengerti) oleh pengguna dalam hal ini guru dan siswa. Efektivitas berarti tercapainya tujuan pembelajaran yang tercermin dalam hasil belajar siswa pada kemampuan pemahaman konsep dan pemecahan masalah matematis siswa.

Uji Field Test (uji lapangan) dilakukan sebanyak lima pertemuan via daring dengan aplikasi getschool dan WhatsApp. Penelitian dilakukan dari tanggal 04 Agustus 2020 sampai dengan 23 agustus 2020. Selama tahap uji lapangan peneliti tetap kesekolah memantau dan melihat jalannya proses pembelajaran. Materi pada pertemuan pertama yaitu membandingkan bilangan pecahan, penjumlahan dan pengurangan bilangan pecahan, perkalian dan pembagian bilangan pecahan, mengenal bilangan berpangkat bulat positif, kelipatan peresekutuan terkecil dan faktor persekutuan terbesar. Selama proses pembelajaran berlangsung via daring pada pertemuan pertama banyak siswa yang bertanya tentang langkah-langkah yang ada pada LKPD. Pada akhir pertemuan dilakukan tes akhir pemahaman konsep dan pemecahan masalah matematis siswa.

\section{RESULTS AND DISCUSSION}

Penelitian yang telah dilakukan dengan Pengembangan Lembar Kerja Peserta Didik (LKPD) dengan Model Pembelajaran Discovery Learning mengacu pada jenis pengembangan model Formative Evalution oleh Tessmer (Plomp, 2007:28) memiliki hasil sebagai berikut:

1. Kemampuan Pemahaman

Konsep Siswa

a. Kelas Eksperimen

Kelas Eksperimen merupakan kelas yang menggunakan model pembelajaran Discovery
Learning. Hasil efektifitas LKPD diperoleh setelah siswa menggunakan LKPD discovery learning. Tes kemampuan pemahaman konsep diujikan kepada 32 siswa berupa soal uraian sebanyak 7 buah soal dan dilakukan diakhir pembelajaran. Hasil belajar kemampuan pemahaman konsep siswa pada kelas eksperimen dapat dilihat pada Tabel 1 berikut ini:

Jurnal JIPS (Jurnal Ilmiah Pendidikan Scholastic) Vol. 5 No. 3 (2021) ISSN : 2579-5449

This work is licensed under a Creative Commons Attribution-NonCommercial 4.0 International License. 
Tabel 1. Persentase Ketuntasan Kemampuan Pemahaman Konsep Siswa Kelas Eksperimen

\begin{tabular}{|c|c|c|c|c|}
\hline & \multicolumn{2}{|c|}{ Ketuntasan } & \multirow{2}{*}{ Total } & $\begin{array}{c}\text { Rata- } \\
\text { Rata }\end{array}$ \\
\cline { 2 - 4 } & Tuntas & $\begin{array}{c}\text { Tidak } \\
\text { tuntas }\end{array}$ & & \\
\hline Jumlah siswa & 23 & 9 & 32 & \multirow{2}{*}{77,59} \\
\hline Persentase & $72 \%$ & $28 \%$ & $100 \%$ & \\
\hline
\end{tabular}

Berdasarkan Tabel 1 diperoleh bahwa dari 32 siswa 23 diantaranya memperoleh nilai di atas KKM . Sedangkan siswa yang nilainya belum mencapai KKM ada 9 orang siswa. Berarti siswa yang tuntas adalah $72 \%$ dari seluruh siswa yang yang mengikuti tes dan siswa yang belum tuntas adalah $28 \%$. Sehingga dapat disimpulkan kemampuan pemahaman konsep siswa dengan menggunakan model pembelajaran Discovery Learning dapat meningkatkan hasil kemampuan pemahaman konsep siswa.

b. Kelas Kontrol

Kelas Kontrol merupakan kelas yang tidak menggunakan LKPD discovery learning. Hasil efektifitas diperoleh setelah siswa diberikan tes pemahaman konsep yang berupa uraian sebanyak 7 buah soal. Tes ini diujikan kepada 31 siswa dan dilakukan diakhir pembelajaran. Hasil belajar kemampuan pemahaman konsep siswa pada kelas kontrol dapat dilihat pada Tabel 2 berikut ini:

Tabel 2. Persentase Ketuntasan Kemampuan Pemahaman Konsep Siswa Kelas Kontrol

\begin{tabular}{|c|c|c|c|c|}
\hline \multirow{2}{*}{} & \multicolumn{2}{|c|}{ Ketuntasan } & \multirow{2}{*}{ Total } & \multirow{2}{*}{$\begin{array}{c}\text { Rata- } \\
\text { Rata }\end{array}$} \\
\cline { 2 - 3 } & Tuntas & $\begin{array}{c}\text { Tidak } \\
\text { tuntas }\end{array}$ & & \\
\hline Jumlah siswa & 18 & 13 & 31 & \multirow{2}{*}{71,09} \\
\hline Persentase & $58 \%$ & $42 \%$ & $100 \%$ & \\
\hline
\end{tabular}

Berdasarkan Tabel 2 diperoleh bahwa dari 31 siswa 18 diantaranya memperoleh nilai di atas KKM . Sedangkan siswa yang nilainya belum mencapai KKM ada 13 orang siswa. Berarti siswa yang tuntas adalah 58\% dari seluruh siswa yang yang mengikuti tes dan siswa yang belum tuntas adalah $42 \%$. Ketuntasan hasil kemampuan pemahaman konsep siswa belum mencapai $70 \%$ dan dinyatakan belum tuntas. Dengan demikian dapat disimpulkan bahwa pemahaman konsep siswa tanpa menggunakan perangkat pembelajaran dalam proses pembelajaran masih tergolong rendah. Ini menunjukkan bahwa pembelajaran kondusif tidak efektif untuk meningkatkan hasil kemampuan pemahaman konsep siswa.
2. Kemampuan Pemecahan Masalah Matematis Siswa

a. Kelas Eksperimen

Hasil efektifitas LKPD diperoleh setelah siswa menggunakan LKPD discovery learning. Tes kemampuan pemecahan masalah diujikan kepada 32 siswa berupa soal uraian sebanyak 3 buah soal dan dilakukan diakhir pembelajaran. Hasil belajar kemampuan pemecahan masalah siswa pada kelas eksperimen dapat dilihat pada Tabel 3 berikut ini:

Tabel 3. Persentase Ketuntasan Kemampuan Pemecahan Masalah Siswa Kelas Eksperimen

\begin{tabular}{|c|c|c|c|c|}
\hline \multirow{2}{*}{} & \multicolumn{2}{|c|}{ Ketuntasan } & \multirow{2}{*}{ Total } & $\begin{array}{c}\text { Rata- } \\
\text { Rata }\end{array}$ \\
\cline { 2 - 4 } & Tuntas & $\begin{array}{c}\text { Tidak } \\
\text { tuntas }\end{array}$ & & \\
\hline Jumlah siswa & 28 & 4 & 32 & \multirow{2}{*}{83,22} \\
\hline Persentase & $87,5 \%$ & $12,5 \%$ & $100 \%$ & \\
\hline
\end{tabular}

Berdasarkan Tabel 3 diperoleh bahwa dari 32 siswa 28 diantaranya memperoleh nilai di atas KKM . Sedangkan siswa yang nilainya belum mencapai KKM ada 4 orang siswa. Berarti siswa yang tuntas adalah $87,5 \%$ dari seluruh siswa yang yang mengikuti tes dan siswa yang belum tuntas adalah 12,5\%. Sehingga dapat disimpulkan kemampuan pemecahan masalah siswa dengan menggunakan model pembelajaran Discovery Learning dapat meningkatkan hasil kemampuan pemecahan masalah siswa.

b. Kelas Kontrol

Kelas Kontrol merupakan kelas yang tidak menggunakan LKPD discovery learning. Hasil efektifitas diperoleh setelah siswa diberikan tes pemecahan masalah yang berupa uraian sebanyak 3 buah soal. Tes ini diujikan kepada 31 siswa dan dilakukan diakhir pembelajaran. Hasil belajar kemampuan pemecahan masalah siswa pada kelas kontrol dapat dilihat pada Tabel 4 berikut ini:

Tabel 4. Persentase Ketuntasan Kemampuan Pemecahan Masalah Siswa Kelas Kontrol

\begin{tabular}{|c|c|c|c|c|}
\hline & \multicolumn{2}{|c|}{ Ketuntasan } & \multirow{2}{*}{ Total } & $\begin{array}{c}\text { Rata- } \\
\text { Rata }\end{array}$ \\
\cline { 2 - 3 } & Tuntas & Tidak tuntas & & \\
\hline $\begin{array}{c}\text { Jumlah } \\
\text { siswa }\end{array}$ & 18 & 13 & 31 & \multirow{2}{*}{72,48} \\
\hline Persentase & $58 \%$ & $42 \%$ & $100 \%$ & \\
\hline
\end{tabular}

Berdasarkan Tabel 4 diperoleh bahwa dari 31 siswa 18 diantaranya memperoleh nilai di atas KKM . Sedangkan siswa yang nilainya belum mencapai KKM ada 13 orang siswa. Berarti siswa yang tuntas adalah 58\% dari

Jurnal JIPS (Jurnal Ilmiah Pendidikan Scholastic) Vol. 5 No. 3 (2021) ISSN : 2579-5449

This work is licensed under a Creative Commons Attribution-NonCommercial 4.0 International License. 
seluruh siswa yang yang mengikuti tes dan siswa yang belum tuntas adalah $42 \%$. Ketuntasan hasil kemampuan pemecahan masalah matematis siswa belum mencapai $70 \%$ dan dinyatakan belum tuntas. Dengan demikian dapat disimpulkan bahwa pemecahan masalah matematis siswa tanpa menggunakan perangkat pembelajaran dalam proses pembelajaran masih tergolong rendah. Ini menunjukkan bahwa pembelajaran tidak efektif untuk meningkatkan hasil kemampuan pemecahan masalah siswa.

3. Hasil Uji Perbedaan Rata-rata

Skor Kemampuan Pemahaman Konsep Siswa

Uji Perbedaan Rata-rata Skor kemampuan pemahaman konsep siswa dilakukan untuk melihat bagaimana pengaruh perbedaan rata-rata kelas eksperimen yang menggunakan LKPD Discovery Learning dan kelas Kontrol yang tidak menggunakan LKPD Discovery Learning. Pengujian ini dilakukan dengan menggunakan Uji-t dengan syarat data harus normal dan homogen. Hasil perhitungan uji-t dapat dilihat pada Tabel 5 berikut ini:

Tabel 5. Hasil Uji-T Kemampuan Pemahaman Konsep Siswa

\begin{tabular}{|l|l|l|l|l|}
\hline Kelas & N & $\begin{array}{l}\text { Rata- } \\
\text { rata }\end{array}$ & $\begin{array}{l}\text { Standar } \\
\text { Deviasi }\end{array}$ & Siginifikansi \\
\hline Eksperimen & 32 & 77,59 & 11,77 & \multirow{2}{*}{0,035} \\
\hline Kontrol & 31 & 71,09 & 12,08 & 0 \\
\hline
\end{tabular}

Dari hasil perhitungan Tabel 5 diperoleh nilai signifikansi $0,035<0,05$ berarti tolak $\mathrm{H}_{0}$. Dengan demikian dapat disimpulkan bahwa penerapan LKPD dengan menggunakan model discovery learning dapat meningkatkan hasil kemampuan pemahaman konsep siswa.

4. Hasil Uji Perbedaan Rata-rata Skor Kemampuan Pemecahan Masalah Matematis Siswa

Uji Perbedaan Rata-rata Skor kemampuan pemecahan masalah matematis siswa dilakukan untuk melihat bagaimana pengaruh perbedaan rata-rata kelas eksperimen yang menggunakan LKPD Discovery Learning dan kelas kontrol yang tidak menggunakan LKPD Discovery Learning. Pengujian ini dilakukan dengan menggunakan Uji-t dengan syarat data harus normal dan homogen. Hasil perhitungan uji-t dapat dilihat pada Tabel 6 berikut ini:

Tabel 6. Hasil Uji-T Kemampuan Pemecahan Masalah Matematis Siswa

\begin{tabular}{|l|l|l|l|l|}
\hline Kelas & $\mathrm{N}$ & $\begin{array}{l}\text { Rata- } \\
\text { rata }\end{array}$ & $\begin{array}{l}\text { Standar } \\
\text { Deviasi }\end{array}$ & Siginifikansi \\
\hline Eksperimen & 32 & $\begin{array}{l}83,2 \\
2\end{array}$ & 11,14 & \multirow{2}{*}{0,001} \\
\hline Kontrol & 31 & $\begin{array}{l}74,4 \\
8\end{array}$ & 12,17 & \\
\hline
\end{tabular}

Dari hasil perhitungan Tabel 6 diperoleh nilai signifikansi $0,001<0,05$ berarti tolak $\mathrm{H}_{0}$. Dengan demikian dapat disimpulkan bahwa penerapan LKPD dengan menggunakan model discovery learning dapat meningkatkan hasil kemampuan pemecahan masalah siswa. Efektifitas LKPD dilakukan setelah LKPD dinyatakan valid dan praktis. Efektifitas LKPD untuk penilaian ini adalah untuk melihat seberapa jauh kegunaan dan manfaat dari LKPD dalam meningkatkan hasil belajar siswa berupa kemampuan pemahaman konsep dan pemecahan masalah matematis siswa. Pada penelitian ini, hasil kemampuan pemahaman konsep dan pemecahan masalah matematis siswa diperoleh dengan memberikan tes diakhir pembelajaran. Tes hasil belajar siswa diberikan setelah menggunakan LKPD discovery learning. Pendapat ini sejalan dengan yang diungkapkan oleh Mudijono dan Dimyati (2006:20) bahwa "evaluasi hasil belajar merupakan proses untuk menentukan nilai belajar siswa melalui kegiatan penilaian atau pengukuran hasil belajar dengan tujuan untuk mengetahui tingkat keberhasilan yang dicapai oleh peserta didik setelah mengikuti kegiatan pembelajaran".

\section{Kemampuan Pemahaman Konsep}

Pemahaman konsep merupakan salah satu tujuan penting dalam pembelajaran matematika. Konsep-konsep merupakan pilar-pilar pembangun untuk berfikir yang lebih tinggi. Dengan mengenal konsep dan struktur yang tercakup dalam bahan yang sedang dibicarakan, anak akan memahami materi yang harus dikuasainya itu, ini menunjukkan bahwa materi yang mempunyai pola atau struktur tertentu akan lebih mudah dipahami dan diingatnya (Erman, 2003:43). Indikator kemampuan pemahaman konsep dalam penelitian ini adalah (a) Menyatakan ulang sebuah konsep; (b) Mengklasifikasi objek-objek menurut sifat-sifat tertentu; (c) Mengaplikasikan konsep atau algoritma pemecahan masalah.

Berdasarkan hasil tes akhir kemampuan pemahaman konsep yang terdiri dari 7 soal diperoleh persentase ketuntasan belajar siswa kelas eksperimen dengan menggunakan LKPD berbasis discovery learning lebih tinggi dari pada siswa kelas kontrol yang tidak menggunakan LKPD discovery learning. Sesuai dengan persentase ketuntasan hasil kemampuan pemahaman konsep siswa yang tuntas mencapai

Jurnal JIPS (Jurnal Ilmiah Pendidikan Scholastic) Vol. 5 No. 3 (2021) ISSN : 2579-5449

This work is licensed under a Creative Commons Attribution-NonCommercial 4.0 International License. 
72\% dengan rata-rata $77,59 \%$. Dari hasil uji analisis perbedaan rata-rata diperoleh nilai siginifikansi $<0,05$ berarti $\mathrm{H}_{0}$ ditolak. Dengan demikian dapat disimpulkan LKPD dengan menggunakan model pembelajaran discovery learning dapat meningkatkan kemampuan pemahaman konsep matematis siswa.

Hal ini membuktikan bahwa pembelajaran dengan discovery learning yang dilakukan dapat meningkatkan hasil kemampuan pemahaman konsep siswa. Hal ini disebabkan bahwa LKPD discovery learning yang dirancang lebih menekankan ditemukannya konsep atau prinsip sebelumnya tidak diketahui, masalah yang diperhadapkan kepada masalah yang direkayasa oleh guru. Sehingga siswa tertarik mengerahkan seluruh pikiran dan keterampilannya untuk mendapatkan temuantemuan melalui soal-soal pemahaman konsep yang ada pada LKPD discovery learning. Hal ini sejalan dengan hasil penelitian yang dilakukan oleh Asnita, (2014) menunjukkan bahwa model pembelajaran dengan discovery learning dapat meningkatkan hasil belajar siswa.

\section{Kemampuan}

Masalah Matematis Siswa

Kemampuan pemecahan masalah merupakan bagian yang sangat penting dalam pembelajaran matematika, karena dalam proses pembelajaran matematika maupun penyelesaian siswa dimungkinkan memperoleh pengalaman baru menggunakan pengetahuan serta keterampilan yang sudah dimiliki untuk diterapkan pada pemecahan masalah yang bersifat tidak rutin. Indikator pemecahan masalah yang digunakan dalam penelitian ini adalah: (a)
Mengidentifikasikan unsur-unsur yang diketahui, yang ditanyakan, dan kecukupan unsur yang diperlukan dari suatu permasalahan, (b) Merumuskan masalah matematik atau menyusun model matematik, (c) Menerapkan strategi untuk menyelesaikan berbagai masalah (sejenis dan masalah baru) dalam atau diluar matematika. (d) Menjelaskan atau menginterpretasikan hasil sesuai permasalahan asal.

Berdasarkan hasil tes akhir kemampuan pemecahan masalah matematis siswa yang terdiri dari 3 buah soal diperoleh persentase ketuntasan dengan menggunakan LKPD discovery learning lebih tinggi daripada kelas kontrol. Persentase ketuntasan hasil belajar siswa adalah 87,5\% dengan rata-rata 83,22. Dari hasil uji analisis perbedaan rata-rata diperoleh nilai siginifikansi < 0,05 berarti $\mathrm{H}_{0}$ ditolak. Dengan demikian dapat disimpulkan LKPD dengan menggunakan model pembelajaran discovery learning dapat meningkatkan kemampuan pemecahan masalah matematis siswa.

Hal ini disebabkan pada LKPD discovery learning materi yang akan disampaikan tidak disampaikan dalam bentuk final akan tetapi siswa didorong untuk mengidentifikasi apa yang ingin diketahui, mencari informasi sendiri sesuai dengan indikator kemampuan pemecahan masalah matematis siswa. Sehingga membuat siswa yang pasif menjadi aktif dan kreatif. Siswa tidak hanya menerima informasi secara keseluruhan dari guru. karena dengan LKPD discovery learning siswa dituntut menemukan informasi sendiri melalui LKPD yang telah dirancang.

\section{CONCLUSION}

Berdasarkan hasil penelitian dan pembahasan efektivitas LKPD kemampuan pemahaman konsep dan pemecahan masalah matematis siswa diperoleh persentase ketuntasan belajar siswa kelas eksperimen dengan menggunakan LKPD berbasis discovery learning lebih tinggi dari pada siswa kelas control siswa kelas VII SMPN 38 Padang.

\section{UCAPAN TERIMA KASIH}

Ucapan terimakasih peneliti sampaikan kepada:
1. Kemendikbud yang telah mendanai penelitian ini melalui hibah Penelitian Dosen Pemula (PDP)

2. LPPM Universitas Ekasakti yang sudah menugaskan, memfasilitasi dan mengkoordinir kegiatan penelitian ini

3. Dekan Fakultas Keguruan dan Ilmu Pendidikan Universitas Ekasakti yang telah memberikan izin survei lapangan selama pelaksanaan penelitian

SMPN 38 Padang yang telah memberi izin dalam pelaksanaan penelitian

Jurnal JIPS (Jurnal Ilmiah Pendidikan Scholastic) Vol. 5 No. 3 (2021) ISSN : 2579-5449

This work is licensed under a Creative Commons Attribution-NonCommercial 4.0 International License. 


\section{Bibliography}

[1]Asnita, Y. 2014. Pengaruh Model Discovery Learning Menggunakan True or False Statement Terhadap Pemahaman Konsep Matematis Siswa Kelas VIII MTsN Tanjung Balit Kabupaten Solok. Artikel Penelitian. Padang: STKIP PGRI Sumatera Barat.

[2]BNSP. (2013). Kegiatan Penilaian Buku Teks Pelajaran Pendidikan Dasar dan Menengah, Jakarta: Departemen Pendidikan Nasional.

[3]Depdiknas. 2008. Panduan Pengembangan Bahan Ajar. Jakarta: Departemen Pendidikan Nasional Direktorat Jenderal Menajemen Pendidikan Dasar dan Menengah.

[4]Dimyati dan Mudjiono. 2006. Belajar dan Pembelajaran. Jakarta: PT. Rineka Cipta

[5]Erman, Suherman dkk. 2003. Strategi Pembelajaran Matematika Kontenporer. Bandung: JICA Universitas Pendidikan Indonesia.

[6]Lia, D. (2018). Effect of Learning Model [1]Discovery of Competence Student Subject Biology Class VIII MTSN Rambah

2014/2015 Academic Year. International
Journal of Progressive Sciences and Technologies, 7(1), 1-7.

[7]Prastowo, Andi. 2011. Panduan Kreatif Membuat Bahan Ajar Inovatif. Yogyakarta: Duva Press.

[8]Plomp, T dan N. Nieveen. 2007. Educational Design Research. Enshede: Netherlands Institute For Curriculum Development (SLO).

[9]Roliza, Eva, Ramadhona, R.,\& Rosmery, L. (2018) Praktikalitas Lembar Kerja Siswa Pada Pembelajaran Matematika Materi Statistika. Gantang, III(1), 41-45.

[10]Sugiyono. (2010). Metode Penelitian Kuantitatif Kualitatif Dan $R \quad \& \quad D$. Bandung : Alfabeta.

[11]Trianto, 2010. Model Pembelajaran Terpadu. Jakarta: Bumi Aksara

[12]Widiastuti, Ani, Yetty Rahelly, dan Syafdaningsih. 2018. Pengembangan Bahan Ajar Bentuk-bentuk Geometri Berbasis Cerita Untuk Anak Usia 5-6 Tahun Di TK Mazharul Iman Palembang. Jurnal Pendidikan Anak, 7 (2), (176-189)

Jurnal JIPS (Jurnal Ilmiah Pendidikan Scholastic) Vol. 5 No. 3 (2021) ISSN : 2579-5449 